\title{
MORPHOLOGICAL CHANGES AND RESISTANCE TO VACCINIA VIRUS INDUCED IN HUMAN AMNION CELLS BY YEAST EXTRACT
}

\author{
Ajanta S. ChakrabortTy* and T. S. L. Beswick \\ Department of Bacteriology and Virology, University of Manchester
}

Plate VIII

IT is not always appreciated that the composition of the medium and the conditions of incubation may profoundly influence the morphology of cells in tissue culture, the rate of virus multiplication and the nature of any cytopathic effect produced.

Thicke et al. (1952) showed that multiplication of poliovirus in tissue culture was greater with Medium " 199 " than with Hanks' solution and ox serum ultrafiltrate. A maintenance medium containing serum and embryonic extract produced a higher yield of herpes simplex virus than did a medium containing serum ultrafiltrate (Scherer, 1953). Melnick and Riordan (1952) noted that cysteine increased the final titre of poliovirus in monkey kidney cells, whereas glycine had the opposite effect; Hanks' solution and cysteine gave a greater yield of virus than any other medium they used. Reissig, Black and Melnick (1956) found that in a medium containing serum, embryonic extract and amniotic fluid, human carcinoma (H.Ep.2) cells infected with measles virus underwent syncytium or giant-cell formation, like that described by Enders and Peebles (1954) in human renal cell cultures. However, when glutamine was added to the medium an elongated, fibroblast-like configuration of the individual cells was produced instead. Melnick et al. (1957) observed that the concentration of glucose influenced the time of appearance of the cytopathic effect due to poliomyelitis virus. The same authors also noticed that the growth and morphology of monkey kidney cells in a protein-free maintenance medium depended on the calcium concentration. We have observed that sera and tissue extracts may delay the appearance of the cytopathic effect even when these contain no demonstrable antibody.

Leerhøy (1966) reported unexpected differences in the morphology of a rabbit cornea cell line (SIRC) maintained in four different kinds of maintenance medium. Monolayers were grown in a medium consisting of Earle's solution supplemented with 10 per cent. inactivated calf serum, 0.057 per cent. Difco yeast extract, 0.17 per cent. lactalbumin hydrolysate, 0.084 per cent. sodium bicarbonate and antibiotics. The sheets that developed consisted of a closely packed pavement of cells of epithelial morphology. After outgrowth, the growth medium was replaced by one of four maintenance media. In Medium " 199 " with 1 per cent. inactivated calf serum, $0 \cdot 224$ per cent. bicarbonate and antibiotics, the cells, within 2 days, assumed the appearance of fibroblasts disposed in whorls. In the second maintenance medium, which was the same as the growth medium except that the serum content was reduced to 1 per cent., the morphology remained essentially unchanged. The third medium, bovine amniotic fluid, caused the cells to aggregate into dense clumps linked by long, thin fibroblast-like cells. In the fourth medium, Eagle's minimal essential maintenance medium (MEM) supplemented with 0.0297 per cent. L-glutamine, the cells retained their epithelial morphology, but became somewhat spindle-shaped and showed a tendency to form whorls. Stationary and rolled cultures maintained well in all four media and supported the growth of rubella virus. The same four media had no effect on the morphology of $\mathrm{RK}_{13}$ cells (Beale, Christofinis and Furminger, 1963) or primary vervet monkey kidney cells.

Received 2 July 1970; accepted 5 Sept. 1970.

* Present address: 741 Reutlingen, Gartenstrasse 34, West Germany. 


\section{MATERIALS AND METHODS}

Tissue culture. Secondary human amnion cell cultures were prepared in $15 \times 1.5 \mathrm{~cm}$ tubes by the method described by Hayashi and LoGrippo (1963).

Media. The following media were used for the human amnion cells. (1) Growth medium. Medium " 199 " (Morgan, Morton and Parker, 1950) $78 \mathrm{ml}$; horse serum (natural clot, unheated) $20 \mathrm{ml}$; sodium bicarbonate, 4.4 per cent. solution, $2 \mathrm{ml}$. (2) Maintenance medium. Medium " 199 " $97 \mathrm{ml}$; foetal calf serum $1 \mathrm{ml}$; sodium bicarbonate, 4.4 per cent. solution, $2 \mathrm{ml}$. (3) Special medium. Medium " 199 " (ten-fold concentrated) $10 \mathrm{ml}$; yeast extract solution $10 \mathrm{ml}$; calf serum (natural clot, unheated) $5 \mathrm{ml}$; distilled water $73 \mathrm{ml}$; sodium bicarbonate, 4.4 per cent. solution, $2 \mathrm{ml}$. All the media contained 100 units of penicillin and $100 \mu \mathrm{g}$ of streptomycin per $\mathrm{ml}$. Medium " 199 " and the horse serum were purchased from Burroughs Wellcome Ltd, UK, and the foetal calf serum from Flow Laboratories, UK. The calf serum was obtained locally. The media were usually freshly prepared, but occasionally were stored for up to a day or two at $-20^{\circ} \mathrm{C}$ before use.

Yeast extract solution. Three batches of yeast extract from two manufacturers were used: Difco, USA, batch no. 453384 and 493534; Oxoid, UK, batch no. 128. The majority of experiments were carried out with batch no. 453384 . However, sufficient observations were made on the other two batches to indicate that they possessed essentially similar properties. Yeast extract solution, 10 per cent. (w/v) in distilled water, was prepared from the dry powder or paste, autoclaved at $121^{\circ} \mathrm{C}$ for $15 \mathrm{~min}$. and stored at $+4^{\circ} \mathrm{C}$.

Stock virus suspension. The vaccinia virus used was originally isolated from a sample of calf lymph and had been passaged frequently in this laboratory. The titre in HeLa cells averaged 107 TCD50 per $\mathrm{ml}$. On the chorio-allantoic membranes of 10-day-old chicks, the titre was $1.3 \times 10^{7}$ p.f.u. per ml (average of two titrations).

Incubation. A hot room $\left(36^{\circ} \mathrm{C}\right)$ was used for the growth of tissue cultures. Some of the test cultures were then maintained in a $37^{\circ} \mathrm{C}$ waterbath. Otherwise a bacteriological incubator was used.

Direct action of yeast extract on vaccinia virus. A $0.2 \mathrm{ml}$ volume of stock virus suspension was mixed with $1.8 \mathrm{ml}$ of special medium and another $0.2 \mathrm{ml}$ with $1.8 \mathrm{ml}$ of regular maintenance medium. These mixtures were held overnight at $4^{\circ} \mathrm{C}$. Two sets of 12 secondary amnion tissue-culture tubes were prepared, one in regular maintenance medium, the other in the special medium. Four tubes in each set were inoculated with $0.1 \mathrm{ml}$ amounts of the vaccinia virus-regular maintenance medium mixture, another four received similar amounts of the vaccinia virus-special medium mixture, and the remaining four tubes were kept as uninoculated controls. All the tubes were incubated for $1 \mathrm{wk}$ at $37^{\circ} \mathrm{C}$ and observed daily.

These two virus mixtures and a third consisting of vaccinia virus in Medium " 199 " with 5 per cent. calf serum were also titrated in 10-day-old chick embryos. The chorio-allantoic membranes were inoculated with $0.1 \mathrm{ml}$ amounts of serial ten-fold dilutions of the virus suspensions ranging from $10^{-1}$ to $10^{-5}$, using four eggs per dilution. All the eggs were incubated at $37^{\circ} \mathrm{C}$ for $48 \mathrm{hr}$ and pock counts were then made.

Growth of vaccinia virus in the presence of yeast extract. One set of 40 tubes of secondary human amnion cells was re-fed with regular maintenance medium and another set with the special medium. Thirty tubes from each set were inoculated with $0 \cdot 1 \mathrm{ml}$ amounts of 1 in 100 stock vaccinia virus suspension. Five tubes were kept as uninfected controls and the remaining five were inoculated with $0 \cdot 1 \mathrm{ml}$ amounts of undiluted stock virus suspension. All tubes were incubated at $37^{\circ} \mathrm{C}$.

At the same time, the thermal inactivation rate of the virus was assessed by inoculating $0 \cdot 1 \mathrm{ml}$ quantities of the 1 in 100 virus suspensions into two sets of twelve tubes containing $1 \mathrm{ml}$ amounts of regular maintenance medium and special medium respectively but no cells. Eight tubes from each set were immediately incubated at $37^{\circ} \mathrm{C}$, and the remaining four tubes were used to determine the inoculum dose of virus. The contents of these four tubes were pooled, serially diluted in Hanks' solution in ten-fold steps and titrated in H.Ep.2 cells, using four culture tubes per dilution. The H.Ep.2 cells were grown in Eagle's MEM (Eagle, 1959) (Burroughs Wellcome Ltd) with 10 per cent. calf serum and antibiotics, and maintained 
in the same medium with 2.5 per cent. foetal calf serum. Similar titrations were carried out on the incubated tubes at $6 \mathrm{hr}$ and $18 \mathrm{hr}$.

In the case of the infected amnion cultures, four with regular maintenance medium and four with special medium were harvested at 6-hourly intervals. Two cultures from each batch of four were frozen and thawed twice and the contents pooled and centrifuged at 2000 r.p.m. for $10 \mathrm{~min}$. The resulting supernatants were titrated in H.Ep. 2 cells. The results represented the total infective virus content of the medium and cells. The medium from the other two tubes was poured off, pooled, centrifuged as above and titrated to give the amount of free, extracellular virus. Titrations were carried out in serial ten-fold steps over the dilution range $10^{-1}$ to $10^{-8}$, with four H.Ep.2 tissue-culture tubes per dilution. Uninoculated cell controls and virus-positive controls, infected with $0.1 \mathrm{ml}$ of stock virus, were included with each titration. Readings were taken after 5 days' incubation at $37^{\circ} \mathrm{C}$.

\section{RESULTS}

\section{Effect of special medium on cells}

Two sets of six tubes of secondary human amnion cells were re-fed with regular maintenance medium and special medium respectively and incubated at $37^{\circ} \mathrm{C}$ for $1 \mathrm{wk}$. The media were changed once when they became acid.

No significant changes were noted in the regular maintenance mediumtreated cultures. Occasional discrete rounded cells appeared within the monolayers (fig. 1), and the cells at the somewhat ill-defined edge of the cell sheet were flattened and polygonal (fig. 2). However, striking and characteristic morphological changes were exhibited by the cultures exposed to the special medium (fig. 3). These showed a continuous monolayer of elongated polygonal cells, which were markedly granular and in some cases appeared multinucleate. In addition, highly refractile rounded cells, aggregated to form characteristic clumps, were scattered on top of the continuous layer. The clumps of rounded cells were discontinuous, although adjacent clumps were often in contact with one another. In the gaps between the clumped cells, the underlying continuous layer of polygonal cells on the glass surface was clearly seen. The edge of the cell sheet was quite different from that of the control cell sheet. It was thick and well defined, and there were many refractile rounded cells adjacent to it (fig. 4). These morphological changes developed after 48-72 hr and increased progressively for the next 2-3 days.

\section{Effect of medium on the cytopathic effect of vaccinia virus}

Two sets of eight tubes of human amnion cells were re-fed with special medium and regular maintenance medium respectively. Half the tubes in each set were inoculated with $0 \cdot 1 \mathrm{ml}$ amounts of vaccinia virus suspension, the remaining tubes serving as controls. After incubation at $37^{\circ} \mathrm{C}$, the infected cells in regular maintenance medium developed typical vaccinia virus cytopathic effects, which progressed to complete destruction of the cell sheet within 3-4 days. The uninfected control cultures in special medium developed the characteristic morphological features already described.

Surprisingly, the infected cultures in special medium showed no viral cytopathic effects, but only the changes seen in the corresponding controls. In 
further experiments, one or two isolated microplaques occasionally appeared about the 7th day, by which time infected cultures in regular maintenance medium were totally destroyed. Some of the tubes showing this late plaque formation were further incubated. The number and the size of the plaques sometimes increased slightly, but the cytopathic effect was quite unlike that found in cultures on regular maintenance medium. These experiments were repeated using incubation temperatures of $35^{\circ} \mathrm{C}$ and $39^{\circ} \mathrm{C}$. Apart from some minor differences in the rate of appearance of cytopathic effects in the infected cells in regular maintenance medium, the results were the same as those obtained at $37^{\circ} \mathrm{C}$. All three batches of yeast extract behaved in an identical manner.

\section{Effect of varying the concentration of yeast extract}

Batches of special medium were prepared, using stock solutions of yeast extract (batch no. 453384) of different concentrations ( 1 per cent. w/v to 10 per cent. $w / v$ ), to give a final concentration range of yeast extract of 0.1 to 1 per cent. in 0.1 per cent. steps. Secondary human amnion cultures were exposed to these various media, as well as to regular maintenance medium; eight tubes were used per concentration step of yeast extract. Four of the eight tubes were infected with $0.1 \mathrm{ml}$ amounts of stock vaccinia virus suspension, the other four tubes serving as controls. All tubes were incubated at $37^{\circ} \mathrm{C}$ for 1 wk.

With final concentrations of yeast extract of 0.6 per cent. and above, both the infected and the control tubes developed the characteristic morphological changes described previously and without any virus cytopathic effect in the infected tubes. With lower concentrations of yeast extract $(0.1-0.5$ per cent.) these morphological changes did not appear in the control tubes and, with the exception of one tube exposed to 0.5 per cent. yeast extract, all the infected tubes showed some degree of virus cytopathic effect. However, even with the lowest concentration of yeast extract $(0 \cdot 1$ per cent.), at 7 days the virus-induced changes were usually less than in the regular maintenance medium tubes. This partial inhibition of cytopathic effects by concentrations of yeast extract below 0.5 per cent. was irregular and varied from tube to tube. In subsequent experiments yeast extract was always used at $0 \cdot 8-1.0$ per cent. final concentration.

The dose-response relation revealed in this experiment, together with the results of further studies in which other substances, such as chick embryo extracts, lactalbumin hydrolysate and extra glutamine, were substituted for or used together with the yeast extract, made it clear that the effects described are specifically and wholly due to the yeast extract. Neither the morphological changes in the cells nor the inhibition of virus cytopathic effects were ever observed in the absence of yeast extract, and they were always produced by media containing $0.8-1.0$ per cent. yeast extract with or without the other additives. Although foetal calf serum was used in the regular maintenance medium and calf serum in the special medium, preliminary experiments had shown that neither the type of serum nor the individual batch of serum affected the behaviour of the yeast extract. 


\section{Effect of $p H$ on yeast-extract activity}

By adjusting the concentration of sodium bicarbonate in the regular and special maintenance medium the activity of the yeast extract was examined within the $p \mathrm{H}$ range $5 \cdot 2-8 \cdot 2$. Cell sheets maintained in both types of medium survived well at all $p \mathrm{H}$ levels. The cells in regular maintenance medium all showed unchanged morphology when uninfected, and typical cytopathic effects when infected with vaccinia virus. Cells treated with the special medium showed the characteristic morphological changes and failed to develop any evidence of cytopathic effect after inoculation of vaccinia virus at all $p \mathrm{H}$ levels. The activity of the yeast extract would therefore appear to be independent of $p \mathrm{H}$, at least within the range $5 \cdot 2-8 \cdot 2$.

\section{TABLE I}

Direct effect of different media on the infectivity of vaccinia virus suspensions for chick embryos

\begin{tabular}{l|c|c|c}
\hline & \multicolumn{2}{|c}{ Virus suspension in medium " 199 " } \\
$\begin{array}{c}\text { Infectivity } \\
\text { of suspension } \\
\text { assayed as }\end{array}$ & $\begin{array}{c}\text { with foetal } \\
\text { calf serum }\end{array}$ & $\begin{array}{c}\text { with yeast } \\
\text { extract and } \\
\text { calf serum }\end{array}$ & $\begin{array}{c}\text { with calf } \\
\text { serum }\end{array}$ \\
\cline { 2 - 3 } & 16 & 14.75 & 12.5 \\
\hline $\begin{array}{c}\text { Average number of } \\
\text { pocks at } 10^{-4} \\
\text { dilution }\end{array}$ & $1.6 \times 10^{6}$ & $1.5 \times 10^{6}$ & $1.3 \times 10^{6}$ \\
\hline
\end{tabular}

Effect of acid and alkaline hydrolysis and fat solvents on yeast extract activity

Treatment with ether or chloroform or boiling with 10 per cent. (v/v) hydrochloric acid or 40 per cent. sodium hydroxide, followed by neutralisation, all failed to affect the activity of the yeast extract. Autoclaving at $121^{\circ} \mathrm{C}$ for $15 \mathrm{~min}$. on two occasions and dialysis against distilled water for 7 days at $4^{\circ} \mathrm{C}$ were also without effect on the activity. Tissue cultures exposed to medium containing the treated extracts underwent the characteristic morphological changes and were resistant to the cytopathic effect of vaccinia virus.

\section{Direct action of yeast extract on vaccinia virus}

Vaccinia virus was not inactivated by overnight treatment at $4^{\circ} \mathrm{C}$ with medium containing 1 per cent. $(\mathrm{w} / \mathrm{v})$ yeast extract. The treated virus produced the same cytopathic effect in amnion cells and at the same rate as virus treated with regular maintenance medium only.

The findings in chick embryos (table I) confirmed that the virus particles were not directly affected by the yeast extract or by any other component of the special medium, including the calf serum. 


\section{Growth of vaccinia virus in the presence of yeast extract}

The results of the growth experiments, carried out as described under Methods, are shown in table II and figs. 5 and 6. These findings indicate that

\section{TABLE II}

Growth of vaccinia virus in secondary human amnion cells maintained in regular maintenance medium and in special medium, and virus thermo-inactivation rates in cell-free media

\begin{tabular}{|c|c|c|c|c|c|c|}
\hline \multirow{4}{*}{$\begin{array}{l}\text { Incubation } \\
\text { time (hr) }\end{array}$} & \multicolumn{6}{|c|}{$\log _{10}$ TCD50 of } \\
\hline & \multicolumn{4}{|c|}{ tissue-culture } & \multirow{2}{*}{\multicolumn{2}{|c|}{$\begin{array}{l}\text { virus in } \\
\text { cell-free } \\
\text { medium }\end{array}$}} \\
\hline & \multicolumn{2}{|c|}{$\begin{array}{l}\text { total virus } \\
\text { (intra- and } \\
\text { extra-cellular) in }\end{array}$} & \multicolumn{2}{|c|}{$\begin{array}{c}\text { free virus } \\
\text { (extracellular) in }\end{array}$} & & \\
\hline & M.M.* & Sp.M. $\dagger$ & M.M. & Sp.M. & M.M. & Sp.M. \\
\hline $\begin{array}{r}0 \\
6 \\
12 \\
18 \\
24 \\
30 \\
36 \\
42\end{array}$ & $\begin{array}{l}5 \\
4 \\
2 \cdot 75 \\
2 \\
4 \cdot 5 \\
6 \\
7 \cdot 5 \\
7 \cdot 75\end{array}$ & $\begin{array}{l}5 \\
4 \cdot 25 \\
4 \\
3 \cdot 5 \\
3 \cdot 25 \\
3 \cdot 25 \\
3 \cdot 25 \\
3 \cdot 5\end{array}$ & $\begin{array}{l}5 \\
3.75 \\
1 \cdot 75 \\
1.75 \\
4 \\
5 \cdot 5 \\
6 \cdot 25 \\
6.25\end{array}$ & $\begin{array}{l}5 \\
4.25 \\
3.75 \\
3.75 \\
3.25 \\
3.25 \\
3.5 \\
3.25\end{array}$ & $\begin{array}{l}5 \\
1 \cdot 75 \\
\ldots \\
\ldots \\
\ldots \\
\ldots \\
\ldots\end{array}$ & $\begin{array}{l}5 \\
3 \cdot 75 \\
\ldots .75 \\
1.75 \\
\ldots \\
\ldots \\
\ldots\end{array}$ \\
\hline
\end{tabular}

vaccinia virus is able to multiply well in human amnion cells in regular maintenance medium, but not in cells exposed to the special medium. The estimated virus inoculum dose was $10^{4}$ TCD50 for HeLa cells, although the base-line titration in H.Ep.2 cells indicated a rather higher dose. The multiplicity of infection was about $0 \cdot 1$. In regular maintenance medium the total virus titre gradually decreased over $18 \mathrm{hr}$ and then rose steeply through the rest of the experiment. In the case of the cells treated with special medium, there was a much smaller decrease in the total virus titre during the first $18 \mathrm{hr}$ and little or no rise during the remaining $24 \mathrm{hr}$ of the experiment.

The titre of extracellular virus in the tissue cultures on regular maintenance medium fell steeply to reach its lowest level by $12-18 \mathrm{hr}$ after inoculation. This was followed by a sharp rise to a maximum at $36 \mathrm{hr}$. The situation was quite different in the special medium-treated cultures. The rate of fall in titre during the first $12 \mathrm{hr}$ was slow compared with that in the regular maintenance medium cultures, and there was only a very small further drop in titre.

The titration of the fluids from the cell-free tubes showed a gradual fall in the titre of virus, at the same rate in both types of medium, presumably due to 


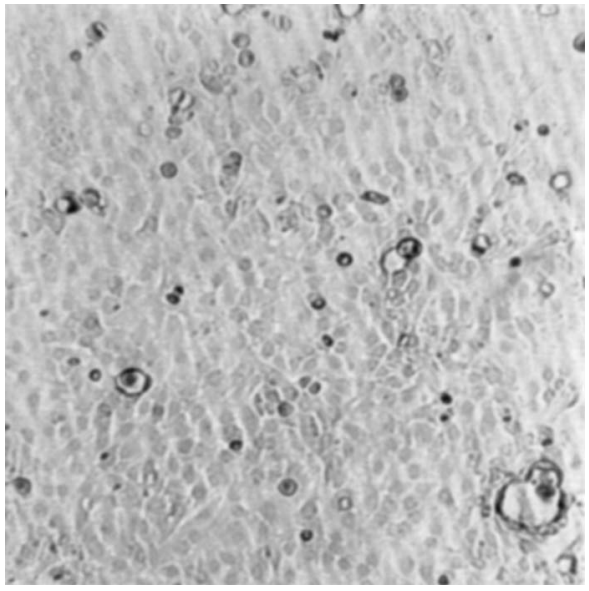

FIG. 1.-Uninfected secondary human amnion monolayer culture in regular maintenance medium. Unstained. $\times 90$.

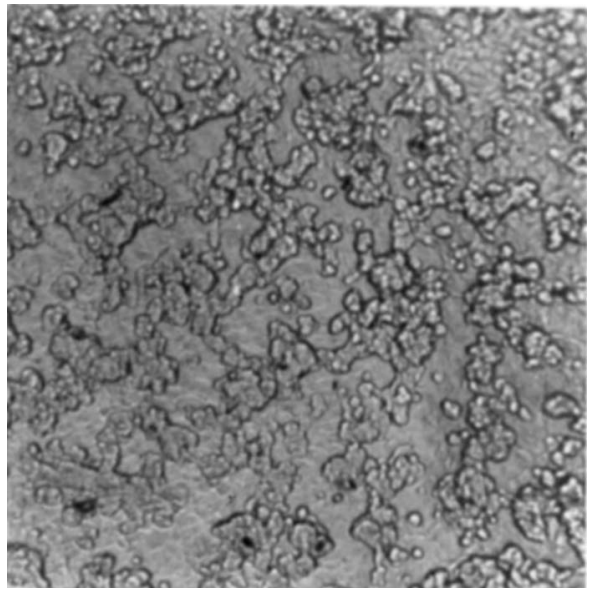

FIG. 3.-Uninfected secondary human amnion culture in medium containing 1 per cent. Difco yeast extract. Unstained. $\times 90$.

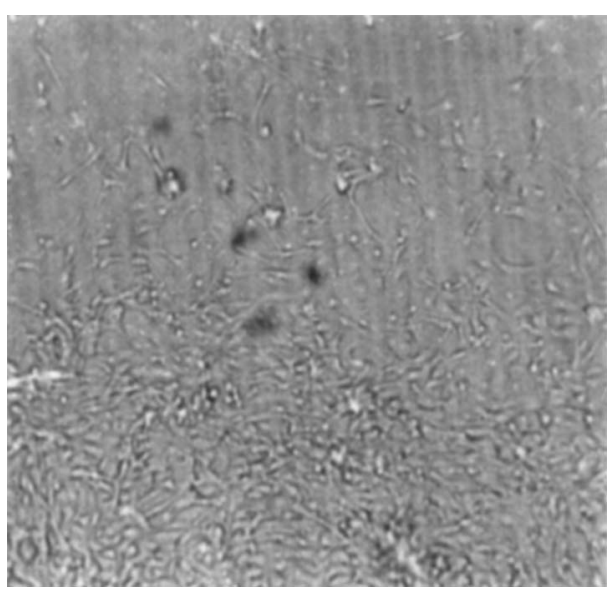

FIG. 2.-As in fig. 1, showing edge of cell sheet. Unstained. $\times 90$.

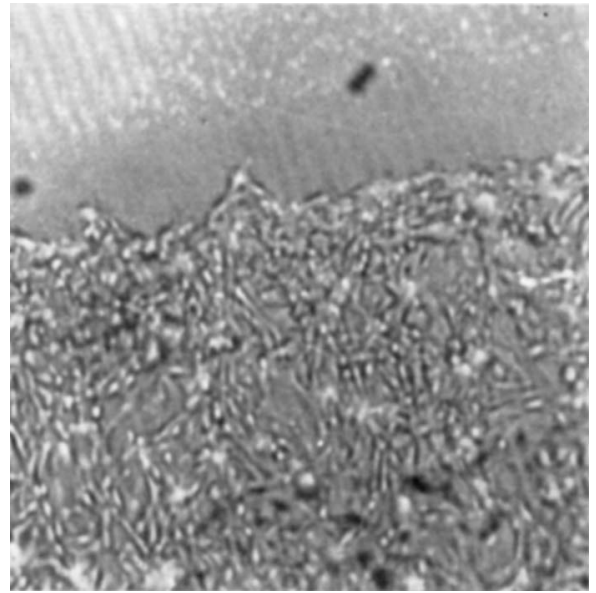

FIG. 4.-As in fig. 3, showing the edge of the cell sheet. Unstained. $\times 90$. 


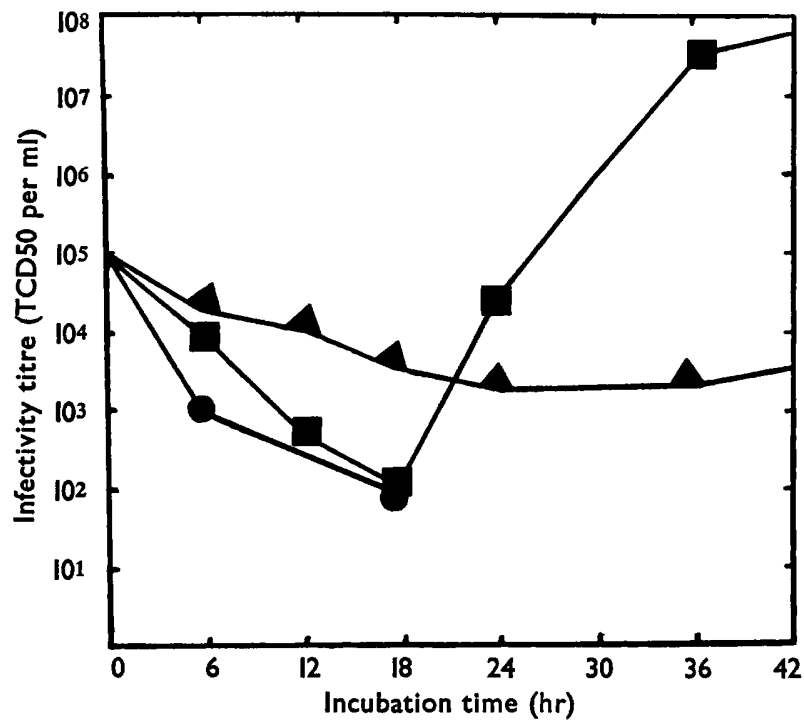

Fig. 5.-Growth curves showing total virus content in amnion cultures maintained in regular maintenance medium and in special yeast-extract medium, and the rate of thermal degradation of virus in regular maintenance medium in the absence of cells. regular maintenance medium-treated cultures; $\boldsymbol{\Lambda}-\boldsymbol{\Lambda}=$ virus titre in yeast-extract-medium cultures; $\bullet-\bullet=$ virus titre in cell-free, regular maintenance medium.

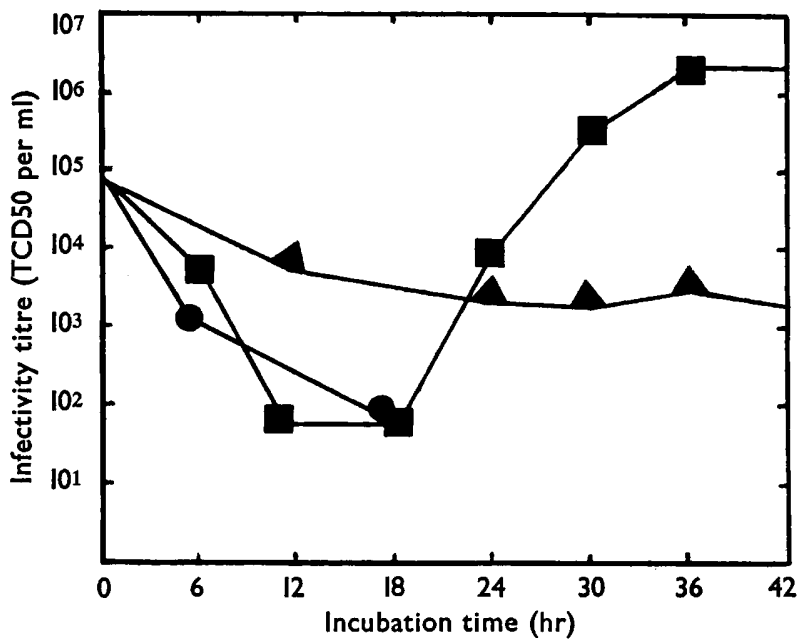

FIG. 6.-Growth curves showing extracellular vaccinia virus content of amnion cultures maintained in regular maintenance medium and in special yeast-extract medium, and the rate of thermal degradation of virus in cell-free 1 per cent. yeast-extract medium. regular maintenance medium-treated cultures; $\Delta-\mathbf{\Delta}=$ virus titre in yeast-extract-medium cultures; $\bullet-\longrightarrow=$ virus titre in cell-free, yeast-extract medium.

thermal inactivation. Although the virus titres in the cell cultures maintained in special medium showed little or no tendency to rise, it is noteworthy that they did not fall as rapidly as in the cell-free tubes containing either medium. 


\section{Discussion}

The present work formed part of a larger study designed to investigate the effect of various components of tissue culture media on the sensitivity of cultured cells to viruses. The findings with yeast extract and secondary human amnion cells were unexpected and it was decided to investigate this system in more detail. It is clear from the results presented above that there is no direct inactivation of vaccinia virus by yeast extract. On the other hand, the results of the growth experiment indicate that the absence of cytopathic effect in the presence of yeast extract is associated with almost total inhibition of virus multiplication. It is not possible to say definitely from the results available whether the inhibition occurs at the stage of attachment, the stage of penetration or the stage of replication of the virus. The only clues come from the fact that the amount of virus in the cultures containing yeast extract did not fall as rapidly as in tubes containing medium but no cells. Obviously, the presence of the cell sheet in some way protected the virus from inactivation. Since this effect is apparent as early as $6 \mathrm{hr}$ after the start of incubation it is difficult to explain it on the basis of limited production of new virus at a rate just about sufficient to counter thermal inactivation; in standard maintenance medium new virus does not begin to appear until about $18 \mathrm{hr}$ after inoculation. That the protective effect is observable for extracellular virus as well as total virus, suggests that it is due to some substance or substances shed by the cells into the medium. Moreover, the growth curves for total virus and extracellular virus in the special medium cultures are practically identical. The only plausible explanation for this finding is that, in the presence of yeast extract, far less virus becomes attached to the cells than in the regular maintenance medium, in which, at $12 \mathrm{hr}$, the concentration of extracellular virus is about one-tenth of the total virus concentration. It therefore seems probable that the action of yeast extract is to block the stage of virus attachment. The striking changes produced in uninfected cell sheets by yeast extract may well represent the morphological expression of an alteration in the chemical and physical properties of the cell membranes. Such a change could well account for failure of the virus to adsorb to the cell.

With regard to the nature of the active principle of the yeast extract, little can be said save that it is resistant to acid and alkaline hydrolysis, is unaffected by lipid solvents and withstands repeated autoclaving. It is active over a wide range of $p \mathrm{H}$. Failure to remove it by dialysis indicates a large particle, although it is small enough to pass through a Seitz EKS filter; in one experiment, not reported, the activity was shown to be unimpaired after passage through a membrane filter of $250 \mathrm{~nm}$ a.p.d.

We have been able to demonstrate these yeast-extract effects only with vaccinia virus and secondary human amnion cells. Similar tests were carried out with a number of continuous and primary cell-types and a variety of viruses, but in no other case did we observe anything comparable to the effects described above. Multiplication of influenza virus type A (PR8), poliovirus type 1 (Sabin), herpes simplex virus and adenovirus type 7 appeared to be normal in 
secondary human amnion cells in the presence of yeast extract, uninfluenced by the morphological changes in the cells.

\section{SUMMARY}

Secondary cultures of human amnion cells developed characteristic morphological changes when re-fed with media containing yeast extract. When cultures so treated were inoculated with vaccinia virus, the usual cytopathic effect failed to develop although isolated microplaques were occasionally observed after prolonged incubation. Some studies were made of the nature of the active substance and its mode of action.

We wish to thank the Research Grants Committee of the United Manchester Hospitals for supporting this project.

\section{REFERENCES}

Beale, A. J., Christofinis, G. C., ANd Furminger, I. G. S. 1963. Rabbit cells susceptible to rubella virus. Lancet, 2,640 .

EAGLE, H. 1959. Amino acid metabolism in mammalian cell cultures. Science, N.Y., 130, 432.

Enders, J. F., AND Peebles, T. C. 1954. Propagation in tissue cultures of cytopathogenic agents from patients with measles. Proc. Soc. Exp. Biol. Med., 86, 277.

HAYASH, H., AND LoGrippo, G. A. 1963. Preparation of primary human amnion cells by pancreatin procedure and their susceptibility to enteroviruses. J. Immun., 90, 956.

LEERHøY, J. 1966. The influence of different media on cell morphology and rubella virus titre in a rabbit cornea cell line (SIRC). Arch. ges. Virusforsch., 19, 210.

Melnick, J. L., Hsiung, G. D., Rappaport, Catherine, Howes, D., and Reissig, MAgDalena 1957. Factors influencing the proliferation of viruses. Tex. Rep. Biol. Med., 15, 496.

Melnick, J. L., AND Riordan, J. T. 1952. Poliomyelitis viruses in tissue culture. IV. Protein-free nutrient media in stationary and roller tube cultures. Proc. Soc. Exp. Biol. Med., 81, 208.

Morgan, J. F., Morton, Helen J., AND Parker, R. C. 1950. Nutrition of animal cells in tissue culture. I. Initial studies on a synthetic medium. Proc. Soc. Exp. Biol. Med., $73,1$.

Reissig, Magdalena, Black, F. L., and Melnick, J. L. 1956. Formation of multinucleated giant cells in measles virus infected cultures deprived of glutamine. Virology, 2,836 .

SCHERER, W. F. 1953. The utilization of a pure strain of mammalian cells (Earle) for the cultivation of viruses in vitro. I. Multiplication of pseudorabies and herpes simplex viruses. Amer. J. Path., 29, 113.

Thicke, Joan C., Duncan, Darline, Wood, W., Franklin, A. E., and Rhodes, A. J. 1952. Cultivation of poliomyelitis virus in tissue culture. I. Growth of the Lansing strain in human embryonic tissues. Canad. J. Med. Sci., 30, 231. 